\title{
Public Choice barriers to efficient climate adaptation - theoretical insights and lessons learned from German flood disasters
}

\author{
ERIK GAWEL* \\ Department of Economics, Helmholtz Centre for Environmental Research - UFZ, Leipzig, Germany \\ University of Leipzig, Leipzig, Germany \\ PAUL LEHMANN** \\ Department of Economics, Helmboltz Centre for Environmental Research - UFZ, Leipzig, Germany \\ University of Oxford, Institute for New Economic Thinking, Oxford, United Kingdom \\ SEBASTIAN STRUNZ*** \\ Department of Economics, Helmboltz Centre for Environmental Research - UFZ, Leipzig, Germany \\ CLEMENS HEUSON ${ }^{* * * *}$ \\ Department of Economics, Helmboltz Centre for Environmental Research - UFZ, Leipzig, Germany
}

\begin{abstract}
In this paper, we take a Public Choice perspective to identify and categorise barriers to efficient public climate adaptation. Specifically, we distinguish three dimensions of public adaptation: extent, structure (form and timing) and organisation (coordination across territorial authorities and policy fields). Within each of these dimensions, we investigate how the self-interest of voters, pressure groups, bureaucrats and politicians may bias adaptation decisions. Thus, we indicate specific barriers to efficient public adaptation. Based on this framework, we illustrate how Germany's response to major flood disasters reflects the incentive structure of concerned stakeholders and their political interaction. The ad hoc character of some public adaptation measures implies a clear bias from the efficient benchmark. In conclusion, we argue that the propositions of Public Choice theory shed some light on how empirical public adaptation processes unfold.
\end{abstract}

\section{Introduction}

In August 2002, severe floods in Central Europe caused 21 deaths and up to 10 bn $€$ damage in Germany alone (Deutsche Rück, 2004; DKKV, 2003).

\footnotetext{
*Email: erik.gawel@ufz.de

**Email: paul.lehmann@ufz.de

***Email: sebastian.strunz@ufz.de

****Email: c.heuson@gmx.de
} 
The subsequent public disaster relief efforts are widely seen as an important reason why the incumbent German government of Chancellor Schröder did not lose that year's general election (e.g., Bechtel and Hainmueller, 2011). Incidentally, in 2013 a major flood disaster again occurred within months of a general election and again the full emergency machinery was set into motion, including an 8 bn $€$ reconstruction fund (BMI, 2013). In contrast, flood events in 2006 and 2010, which entailed lower and more regionally concentrated damages were less mediatised and were not met with major public relief. This example illustrates that the characteristics of public adaptation measures - i.e., measures that are initiated and implemented by governments to offset the impacts of climate change (McCarthy et al., 2001: 982) ${ }^{1}$ - are heavily affected by political considerations. ${ }^{2}$ Similar experiences have been reported for a variety of public adaptation measures worldwide (e.g., disaster relief in the United States, see Congleton, 2006; Eisensee and Strömberg, 2007; Shughart II, 2006).

Against this background, our paper contributes to a growing debate on barriers to and drivers of public adaptation (Klein et al., 2014). This debate has been fuelled by numerous case studies, e.g., for flood management (see, e.g., Falaleeva et al., 2011; Lebel et al., 2011; Næss et al., 2005; Penning-Rowsell et al., 2006; Runhaar et al., 2012; Schanze et al., 2008). Moreover, frameworks have been developed to classify barriers to adaptation (see, e.g., Eisenack and Stecker, 2012; Klein et al., 2014; Lehmann et al., 2015; Moser and Ekstrom, 2010; Sovacool et al., 2015). Case studies and frameworks point towards the importance of institutional and actor-specific barriers. However, research on understanding the causal relationships underlying these barriers is still limited. In fact, the research focus needs 'to change from the inventory questions of "if" and "which" barriers to adaptation exist towards more analytical questions as to "why" and "how" these barriers emerge' (Biesbroek et al., 2013: 1128).

This paper addresses one specific 'why' question in more detail: Why may political decision-makers lack incentives to adopt an efficient level of public adaptation - even if they have sufficient information and resources? We employ Public Choice theory which draws on the implications of self-interest driven behaviour of political actors maximizing their personal utility. Fundamental questions read 'Which societal groups are involved in the political process?', 'What kind of interests do they pursue?', 'How does policy affect these interests?' and 'How do these groups interact and take influence on the political process?'

1 We understand 'public adaptation' as a synonym for 'planned adaptation', to which recent assessment reports of the Intergovernmental Panel on Climate Change refer (e.g., Klein et al., 2014).

2 We are aware that flood management is oftentimes considered a policy field that only partly overlaps with public adaptation. See, for example, the EU Directive 2007/60/EC on the assessment and management of flood risks. 
These questions may be addressed cursorily in some of the case studies and frameworks. However, we are only aware of a few studies which apply Public Choice theory rigorously to analyse public adaptation. Michaelowa (2001) uses the approach to discuss the relationship between climate change mitigation and adaptation on a general level. Michaelowa and Michaelowa (2011) deploy Public Choice theory to explain why development aid is relabelled as climate aid. Congleton (2006) and Shughart II (2006) explain the failure of governments to prepare and respond to natural disasters by the interests of politicians. Schwarze and Wagner (2007) analyse interest groups' specific preferences for selected types of natural disaster insurance. Yet, to date, this strand of research is largely fragmented and there is no comprehensive framework to analyse adaptation from a Public Choice perspective.

This paper aims at filling the above gaps by employing a broader Public Choice perspective for understanding deviations between the empirically observed and the efficient design of public adaptation measures. We analyse public adaptation along the three dimensions of extent, structure (form and timing) and organisation (coordination across territorial authorities and policy fields). For each dimension, we outline how the self-interest driven behaviour of political stakeholders affects decisions. To illustrate the theoretical arguments, we review the experiences from several severe flood events in Germany. Indeed, we find that Public Choice presumptions well explain the empirical evidence of flood risk management in Germany. Obviously, our analysis does not imply that a Public Choice approach alone is sufficient to understand barriers to public adaptation. Instead, we aim to explore to what extent observed deviations from efficient public adaptation are in line with predictions of Public Choice theory.

The paper is organised as follows. Section 2 introduces the basic Public Choice perspective. Building upon this framework, barriers to efficient public adaptation are investigated with respect to extent, structure and organisation. In Section 3, we illustrate the results from this analysis via the example of German flood risk management. Finally, Section 4 concludes.

\section{A public choice perspective on public adaptation}

In the following, we outline dimensions of public adaptation and the respective premises of Public Choice theory. Acknowledging these premises, numerous biases between efficient and politically preferred public adaptation decisions can be expected.

\section{Conceptual basics of public adaptation}

\section{Three dimensions of public adaptation}

The analysis focuses on three well-established dimensions of public adaptation (e.g., Smit et al., 1999), all of which involve institutional choices: (1) extent (i.e., 
the basic choice between providing adaptation through markets or government intervention), (2) structure (i.e., the timing and form of government intervention) and (3) organisation (i.e., the coordination of government intervention across policy levels and fields). ${ }^{3}$

First, consider the extent of public adaptation, as exemplified by the issue of emergency relief. ${ }^{4}$ Public authorities have to decide on the extent of emergency relief to be provided in case of (catastrophic) extreme weather events. In many European countries, such schemes of governmental emergency relief co-exist with market-based insurance against natural hazards (Porrini and Schwarze, 2014; Raschky et al., 2013). Since public and private adaptation might be substitutes, governmental relief programs may crowd out private insurance (socalled 'charity hazard', see Raschky and Weck-Hannemann (2007), but also opposing empirical evidence from Browne and Hoyt (2000)). The prospect of (seemingly costless) ${ }^{5}$ public aid may lead to moral hazard on the part of private actors which refrain from buying insurances or investing in preventive measures. Consequently, the profitability of offering hazard-related insurances decreases and forces some providers to leave the market. Thus, the remaining companies are forced to raise premiums for covering costs, which in turn induces a downshift in demand and hence an even lower supply and higher prices. This kind of vicious circle is known as 'disaster syndrome' (Kunreuther and Pauly, 2004).

Second, the structure of public adaptation relates to timing and form of adaptation measures. With respect to timing, Smit et al. (1999) differentiate between anticipatory ${ }^{6}$ measures that aim at alleviating adverse impacts of climate change ex ante, i.e., before these occur, and reactive measures, that are implemented ex post, i.e., as response to a specific damage. Within ex-post measures in response to catastrophic events, one may further distinguish between relief, made in the immediate aftermath of a catastrophe and recovery measures such as reconstruction (Dari-Mattiacci and Faure, 2015). With respect to form, adaptation may be nature-based ('green' infrastructures like flood retention

3 We focus on three important institutional dimensions, being aware that there are more institutional aspects which need to be considered, e.g., when it comes to understanding adaptive capacity of institutions (see, e.g., Gupta et al., 2010; Oberlack, 2016).

4 Some authors exclude disaster relief from the very definition of adaptation. We do not follow this view for two reasons. First, disaster relief represents a public form of insurance (without explicit premium payments), and insurance is generally seen as a form of adaptation. Second, even if disaster relief were excluded from a narrow definition of adaptation, due to the numerous behavior-related interactions between precaution on the one hand and relief as well as recovery efforts on the other hand, the latter need to be part of our analysis of barriers to efficient adaptation.

5 Individuals often suffer from fiscal illusion, in that they do not fully acknowledge that government expenditures will have to be refinanced via taxation. Hence, the actual cost of public adaptation is underestimated (Michaelowa, 2001).

6 In the flood risk management literature, the term preventive is common. In order to emphasize the dimension of time, we use the terms anticipatory/reactive here. 
areas), technical (physical infrastructures like dikes) and/or societal (institutions, like early-warning systems or insurance) (Gill et al., 2007; Michaelowa, 2001).

Third, the organisation of public adaptation refers to coordination across territorial authorities (at the same policy level as well as at different policy levels) and across policy fields (Mickwitz et al., 2009). In both respects, responsibilities of the different actors have to be allocated and integrated. The eventual decisions on adaptation measures often reside with local actors, though their decisions are usually embedded into a regulatory framework set by higher levels of governance (Measham et al., 2011: 894). Within this multi-level governance framework, national authorities may promote activities at lower levels by assigning an explicit mandate, providing information or transferring resources. Also, there may be agreements between authorities at the same political level, e.g., between regions, to internalise regional externalities and spill-over effects. However, regional and national laws and regulations, such as fiscal transfer systems or national insurance schemes, may also produce adverse incentives for local decision-makers and result in maladaptation (e.g., Corfee-Morlot et al., 2011; Eisenack and Stecker, 2012). In addition, public adaptation may be understood as a new policy field which requires new institutions. Alternatively, it may be integrated into existing sectoral procedures and responsibilities of decisionmaking (UNDP/UNEP, 2011). Empirical studies argue that such 'mainstreaming' is usually required but hardly implemented (e.g., in disaster management, see Beck et al., 2009; Mickwitz et al., 2009).

\section{Actors involved in public adaptation}

Figure 1 sketches the main stakeholders that are typically involved in representative democracies' decision-making on public adaptation and their interactions (for a broad overview, see Michaelowa, 2001). On the one hand, there are actors supplying public adaptation. They involve politicians, whose main interest is to maximise political support (e.g., votes). Consequently, their behaviour is strongly oriented towards both the median voter's preferences and their term of office. Therefore, the electoral cycle often transforms into a 'political budget cycle' where proximity of an election induces a 'consumption binge' to curry favour with voters (Rogoff, 1990). Upon political decisions, the public adaptation measures are designed and implemented by bureaucracies. However, bureaucrats may also be interested in 'salary, perquisites of the office, public reputation, power, patronage and output of the bureau' (Niskanen, 1971: 38). In other words, bureaucracies may strive for budget maximisation which induces excess public adaptation (type I barrier). Then again, bureaucracies may also increase their rents by producing any given output level at a higher cost. They may artificially increase their production costs by on-the-job consumption or excess staff (so-called slack maximisation, e.g., Wyckoff (1990)). As a consequence, 
Figure 1. Overview of actors driving public adaptation, their interests as well as relationships between actors.

Supply of

public adaptation

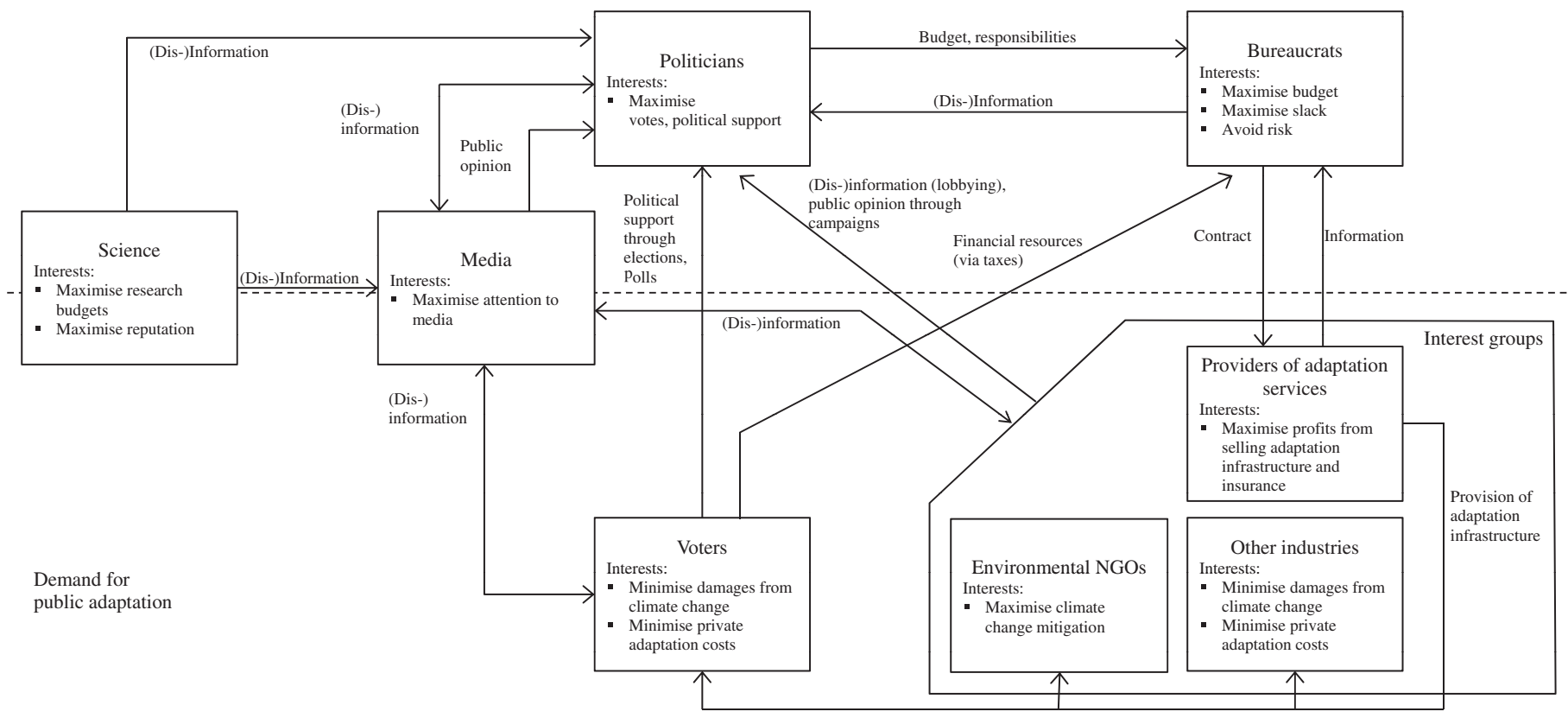


an inefficiently low output level (type II barrier) ensues, possibly aggravated by risk-averse bureaucrats (Mueller, 2003: 368).

On the other hand, there is a set of actors affecting the demand for public adaptation. Voters long for government action that keeps potential residual damages associated with climate change at the lowest possible level without incurring any extra costs (imposed through taxes they pay to bureaucracy). ${ }^{7}$ This also implies that voters exposed to flood risk differ from non- or lessexposed voters in this respect. Also, different voter groups benefit from different adaptation measures. Consider two forms of flood protection: Farmers may reject the conversion of agricultural land into river retention areas while homeowners may object to the construction of levees close to their homes. Increasingly, voters do not only express their will through elections but also through the continuous provision of (dis-)information through social media. In addition, public adaptation is affected by interest groups (see, e.g., Krueger, 1974; Stigler, 1971). These include the providers of adaptation services both in terms of infrastructure and insurance. Construction companies and other providers of technical infrastructure favour technical adaptation measures. Insurance companies lobby for a broad set of anticipatory measures that may help to limit the extent of damages. Moreover, non-governmental organisations (NGOs), engage in lobbying. For instance, development NGOs will push the adaptation needs in developing countries while environmental NGOs will prefer green adaptation. Campaigns launched by interest groups may change public opinion which may affect politicians' decisions indirectly (changing voters' preferences) and directly (because politicians anticipate potential losses in popularity). Additionally, (social) media play a crucial role in agendasetting (e.g., Eisensee and Strömberg, 2007) and influencing voters' demand for adaptation by reporting on negative impacts or potential threats due to climate change. As for interest groups, media's influence on policy-making may be indirect (affecting voters' choices) as well as direct (policy-makers responding immediately to changes in public opinion). A basic interest of media consists in raising attention to increase the number of recipients and income from advertising. Finally, science has taken a prominent role in agenda-setting for climate policy. Scientists also pursue personal interests: In order to maximise research budgets and reputation they may strategically provide information to media, politicians and other stakeholders.

In the following, we scrutinise how these various actors and interest groups affect decision-making regarding the extent, structure and organisation of public adaptation.

7 Certainly, in some countries there may also be a substantial share of population not having the right to vote. We will abstain from such peculiarities in the following. 


\section{The extent of public adaptation}

From a normative economic perspective, the extent of adaptation would be efficient if social marginal benefits equal costs. However, Public Choice barriers may either cause unnecessary government intervention or lead to inefficiently low public adaptation. In other words, over- (marginal costs exceed marginal benefits of adaptation, type I barrier) or underinvestment (marginal benefits exceed marginal costs, type II barrier) may occur.

Following Downs (1957), the self-interest of politicians translates into vote maximising behaviour. At first glance, this endeavour should induce politicians to meet voters' needs and hence foster an optimal adaptation outcome. However, vote maximisation creates incentives for politicians to manipulate cost-benefit assessments of public adaptation measures. Consequently, the political costbenefit analysis does not necessarily reflect the true social costs and benefits (Blankart, 2011: 494). Consider, for instance, levee construction. In terms of benefits, politicians do not only account for social benefits, i.e., the (expected) amount of avoided damages, but additionally assess the expenditures for the construction and maintenance of the levee. These yield profits for local enterprises and stimulate private demand, which fosters the probability for being re-elected. With respect to the costs-side, the levee's political opportunity costs are to be factored in. Public means committed to the levee cannot be used to serve the demands of other interest groups. Additionally, any tax increases to finance the levee would diminish voter support. The respective loss of votes overstates the costs within the political cost-benefit analysis compared to the social optimum. On balance, the additional components stemming from the politicians' votemaximising behaviour on the benefit side lead to an excess (type I barrier), while those on the cost side lead to a lack of public adaptation (type II barrier). Such distortions are aggravated if benefits and costs materialise at different political levels.

Furthermore, voters' preferences constituting the demand for public adaptation not necessarily transport the true social benefits. They hinge crucially on private households' awareness of adaptation need and options. This is aggravated by the fact that adaptation measures are often not easy to define and delimit from measures belonging to other public fields of action (which part of flood risk management policy is due to climate change?). For the general public it is thus difficult to state a clear preference for adaptation at all (Heuson et al., 2012). Combined with highly uncertain and often longterm impacts and bounded rationality of individuals in terms of temporal inconsistencies, the general public's preferences are likely to underrepresent the true social benefit of public adaptation (type II barrier). However, climate change related extreme weather events and resulting damages increase voters' demand for public adaptation (Bryant et al., 2000). The latter might additionally be boosted by the media, which have - except for catastrophic events causing a high public attention and increasing sales - a limited interest 
in reporting on adaptation-related issues (Michaelowa, 2001). Moreover, as Eisensee and Strömberg (2007) show, even catastrophes compete with other newsworthy events for scarce media attention; since public emergency relief is positively correlated with media coverage (ibid.), there is possibly a temporary excess of demand for public adaptation (type I barrier) in the aftermath of highly publicised catastrophic events, which however shrinks over time until a new event occurs. Science may also have an incentive to push for (excessive) public adaptation as this may increase public expenditures for related research.

Private providers of adaptation services increase profits with rising sales and thus push for a level of public adaptation above the optimum (type I barrier). In contrast, environmental NGOs consider adaptation as distraction from climate change mitigation. Thus, these groups only support measures which generate environmental co-benefits, such as the re-establishment of natural retention areas - which possibly creates type II barriers (Michaelowa, 2001). The influence on the extent of public adaptation emanating from other NGOs is less clear-cut. Typically, these groups prefer public measures in specific sectors or fields of action, such as health- or development-related measures, which makes it hard to appraise their influence on total public adaptation. An exception is development NGOs having a clear interest in high levels of public adaptation as these are often means to attract additional development aid.

Which of the (interest) groups is likely to prevail? Following Stigler (1971) and Peltzman (1976), policy makers choose the level of public adaptation that maximises political support of the various groups. This implies trading off losses and gains in support arising from opposed goals of the various groups. As Olson (1971) emphasized, a group's influence depends on its capability in getting organised. Thus, the unorganised group of private households as well as small firms that are not part of the adaptation industry probably play a minor role in influencing the extent of public adaptation due to the very large group size and a lack of clear and strong preferences. NGOs often lack a strong financial basis and homogenous preferences among their group members with respect to public adaptation. The opposite applies for providers of adaptation services and large firms of other industries. They exhibit a rather small group size, financial strength and thus have access to media. Moreover, they pursue a clear homogenous goal which is maximising sales of adaptation services or passing on adaptation costs to the public, respectively. As a result, there is a tendency for the type I barriers to be dominating on the demand side.

On the supply side, bureaucracies implement public adaptation (Mueller, 2003: 359). As described above, bureaucrats may exhibit three types of self-interest that may distort outcome: budget maximisation, slack maximisation and risk aversion. Note that the bureaucrats' ability to manipulate the output level in each of the three cases requires an informational advantage regarding the cost of adaptation and the inability of the politicians to monitor the bureaucrats 
without (considerable) costs. Thus, adaptation offers scope for enforcing the bureaucrats' self-interests. Adaptation measures are typically fuzzy and hard to delimit from measures related to other political fields of action. Moreover, there is neither a public budget which is especially dedicated for purposes of adaptation, nor do clear-cut success metrics exist for evaluating the adaptation output. All these characteristics help the bureaucrats to disguise their true costs and efforts in terms of adaptation.

\section{The structure of public adaptation}

Economic theory suggests that in terms of timing, adaptation investments should be postponed as long as the benefits of postponement (avoided investment costs) are greater than the associated costs (higher climate change damages). As regards the form of adaptation, efficiency demands an explicit solution of trade-offs so as to equate marginal benefits across measures (for an overview of the economics of climate adaptation, see Heuson et al., 2012). Yet in practice a number of Public Choice barriers to efficiency are to be expected.

First, the discrepancy between political and social cost-benefit assessments (Blankart, 2011: 494) may induce distorted adaptation, regardless of any influence of the demand or supply side. With respect to timing, one major source of distortion is given by the politicians' limited time-horizon. Due to their focus on being (re-)elected, they tend to excessively discount costs and benefits that accrue beyond their term of office. ${ }^{8}$ Even within the electoral cycle, the political benefits of implementing adaptation measures are not evenly distributed over time: The attention cycle or political 'budget cycle' (Rogoff, 1990) implies that the political payoff from a measure increases when an election is approaching. Furthermore, in the immediate aftermath of a catastrophe vanishing political opposition against crisis-related policies may enable politicians to present themselves as successful crisis managers (Fidrmuc and Tichit, 2013). Consequently, the timing of public adaptation may be biased in favour of reactive measures, since these promise immediate and rather certain political benefits (public attention, media notice, etc.). Moreover, reactive measures, such as emergency relief, can be pointedly used for boosting the chances of being re-elected, as demonstrated in the previous section. In contrast, anticipatory adaptation usually involves immediate costs but uncertain and remote benefits and hence diminishes the chances of being re-elected. Within ex-post measures, it has been argued that '[r]elief is less likely than recovery to generate over-supply by the government and over-reliance by victims' (Dari-Mattiacci and Faure, 2015: 180). This is because relief and ex-ante precaution are complements while recovery aid may substitute for precaution: Immediate relief reduces the social cost of a flood disaster while recovery aid

8 There is an ongoing heavy dispute on which of these rates to apply to cost-benefit assessments supporting policy decisions, especially concerning climate change (Blankart, 2011: 491). 
just redistributes the cost of rebuilding from the concerned individuals to the state.

Concerning the form of adaptation, there is no such obvious bias emerging from the political cost-benefit assessment. However, elected representatives may be inclined to follow voters' preference for green and technical over societal adaptation measures due to the formers' visibility, (possibly deceptive sense of) security, relatively fast implementation (e.g., as compared to long-term renaturation of river basins) and fiscal illusion on the part of the voters.

Bureaucracies may favour anticipatory measures because they increase budget in the near future while reactive measures only involve uncertain increases in budget - both with respect to occurrence and point of time. However, budget maximisation and slack maximisation are not tied to specific forms of adaptation (Michaelowa, 2001). On the one hand, green and technical adaptation measures typically involve high budgets. On the other hand, societal adaptation is similarly attractive when it can be differentiated in many single measures. If bureaucrats are risk averse, they will favour reactive measures since these grant largely certain benefits while the benefit of anticipatory measures depends on highly uncertain climate change impacts.

To sum up, the supply side is subject to incentives for both fostering anticipatory and reactive measures. However, considering that the strive for attaining budget as early as possible concerns both budget and slack maximisation, this aspect probably outweighs the comparative advantage of reactive measures in generating (slightly) lower risk in terms of benefits. Hence, bureaucracy presumably tends to distort the outcome of public adaptation towards anticipatory measures.

What type of structure bias can be expected from the demand side? As stated above, unorganised voters, i.e., private households generally tend to show weak preferences for (public) adaptation due to unawareness with respect to the availability and necessity of adaptation and temporal inconsistencies (see section Conceptual basics of public adaptation). Consequently, their call for public adaptation significantly rises in the aftermath of extreme events (Bryant et al., 2000). This clearly suggests that voters push for reactive instead of anticipatory measures. Additionally, the voters' influence is likely to bias the mix of public adaptation towards green and technical measures since these are more strongly perceived compared to societal ones (Michaelowa, 2001) - especially when it comes to removing damages after catastrophic events. An exception in this regard may be given by direct financial compensation for obvious reasons. This trend is likely to be reinforced by the media. In terms of climate change, their focus is mainly on such events as these cause considerable public attention and hence promise to increase sales. Thus, news coverage similarly concentrates on the most visible public responses.

Providers of adaptation infrastructure obviously lobby for technical measures, while insurance companies will prefer societal ones. Furthermore, the providers 
Table 1. Structure of public adaptation - overview of stakeholder incentives

\begin{tabular}{|c|c|c|c|c|}
\hline & \multicolumn{2}{|c|}{ Timing } & \multicolumn{2}{|c|}{ Form } \\
\hline & Anticipatory & Reactive & Technical & Societal \\
\hline Drivers & $\begin{array}{l}\text { - Bureaucratic budget } \\
\text { maximisation and } \\
\text { slack maximisation } \\
\text { - Adaptation industry's } \\
\text { profit maximisation }\end{array}$ & $\begin{array}{l}\text { - Bureaucratic } \\
\text { risk aversion } \\
\text { - Political } \\
\text { discounting }\end{array}$ & $\begin{array}{l}\text { - Federalism } \\
\text { - Adaptation industry's } \\
\text { profit maximisation } \\
\text { - Voters' perception of } \\
\text { security }\end{array}$ & $\begin{array}{l}\text { - Environmental } \\
\text { NGOs push for } \\
\text { mitigation and } \\
\text { natural } \\
\text { adaptation }\end{array}$ \\
\hline
\end{tabular}

might push for anticipatory measures since these promise a secure and steady flow of income as compared to uncertain, erratic income from reactive measures. Small companies of other industries, similarly to private households (see section Conceptual basics of public adaptation), basically show a low interest in adaptation and thus prefer reactive, technical measures or direct financial compensation. On the contrary, large companies are more sensitive to risks associated with climate change and thus probably lobby for anticipative measures to rule out any detrimental effects on revenues and competitiveness from the beginning. In terms of adaptation form, there is no compelling reason for preferring technical or societal measures as long as they redound to the firms' advantage. Environmental NGO's tend to dismiss adaptation for being a distraction from the - in their eyes - more promising option of mitigation. Also, since technical adaptation usually conflicts with goals of nature preservation, environmental NGOs have a clear preference for green and societal adaptation.

Following the line of argument in the section Conceptual basics of public adaptation, which builds upon Olson's (1971) theory on interest groups, it can be argued that the providers of adaptation infrastructure and large firms from other sectors are likely to exert the strongest influence on the policy maker. Consequently, the overall demand-side influence on the structure of public adaptation presumably leads to a bias towards anticipatory and technical measures.

Aggregating all stakeholder interests with respect to the form of adaptation (cf. Table 1) suggests that preferences for technical adaptation may dominate. Concerning timing, the political sector faces pressure towards anticipatory measures from both the supply and demand side, while it prefers reactive measures. Whether policy makers defer to this pressure depends on the strength of their preferences for reactive action, i.e., on how strong they discount future benefits of anticipatory measures.

\section{The organisation of public adaptation}

The economic discussion of coordination of public adaptation across territorial authorities is primarily associated with the theories of fiscal federalism. Overall, 
administrative responsibility should correspond to the scale of the public good: Local (national) public goods should be provided by the local (national) level (Musgrave, 1959; Oates, 1972; Olson, 1969). For instance, flood management should be coordinated at the scale of a river basin so as to internalise external effects from upstream regions on downstream regions. Furthermore, benefits of both decentralisation (e.g., interjurisdictional competition (Tiebout, 1956)) and centralisation (e.g., economies of scale (Inman and Rubinfeld, 1997)) should be acknowledged. Concerning coordination of public adaptation across policy fields, mainstreaming is advocated to facilitate synergies with neighbouring policy fields, thereby reducing adaptation cost (Füssel, 2007; Füssel and Klein, 2004; UNDP/UNEP, 2011).

Regarding coordination of public adaptation across territorial authorities, several Public Choice explanations for excessive centralisation have been emphasized (Vaubel, 1994). First, politicians and bureaucrats of the central government aim at increasing their voter base, power and budget by concentrating government functions at their level. For higher level politicians, the incentive to centralise may be particularly strong when local adaptation decisions would be taken by politicians of rival parties. In this case, benefits from public adaptation would be associated with the rival party and might negatively affect the election results of the governing party at the central level. Second, politicians and bureaucrats of lower level governments may also find it preferable to shift responsibilities to the higher level. Regions with ambitious environmental programs may lobby for policy harmonisation through federal legislation to avoid competitive disadvantages with other regions. In a similar manner, local governments may promote the centralised provision of public goods as a means of inter-region income redistribution (e.g., if the income of the median voter in the region is below the federal average). Importantly, given a certain degree of centralisation, politically unpopular decisions may be pinned on the central government. In fact, local actors can hardly justify adaptation measures in the presence of competing planning interests without a clear mandate from a higher authority (e.g., Corfee-Morlot et al., 2011; Measham et al., 2011). Finally, centralisation may also be promoted by those local politicians and bureaucrats who hope to be promoted to the higher level in the future. Obviously, these considerations of politicians and bureaucrats of lower level governments compete with the basic interest of maintaining and extending a certain degree of regulatory power. Thirdly, interest groups with nationally homogeneous interests may try to foster centralisation as a means of improving their bargaining position: Centralisation increases information costs for the government, whereas the interest groups' transaction costs of rent-seeking decrease.

Regarding coordination of public adaptation across policy fields, voters and therefore also politicians may prefer mainstreaming because it may reduce or at least conceal the cost of adaptation. What is more, mainstreaming facilitates 
Table 2 Organisation of public adaptation - overview of stakeholder incentives

\begin{tabular}{|c|c|c|c|c|}
\hline & \multicolumn{2}{|c|}{ Across territorial authorities } & \multicolumn{2}{|c|}{ Across policy fields } \\
\hline & Centralised & Decentralised & Mainstreaming & No mainstreaming \\
\hline Drivers & $\begin{array}{l}\text { - Lower level } \\
\text { bureaucratic risk } \\
\text { aversion } \\
\text { - Higher level } \\
\text { bureaucratic budget } \\
\text { maximisation } \\
\text { - Interest groups: } \\
\text { decrease lobbying } \\
\text { costs } \\
\text { - Central government: } \\
\text { max. voter base and } \\
\text { power } \\
\text { - Lower level } \\
\text { government: shift } \\
\text { responsibilities for } \\
\text { unpopular decisions }\end{array}$ & $\begin{array}{l}\text { - Lower level } \\
\text { government: } \\
\text { secure decision- } \\
\text { making } \\
\text { power }\end{array}$ & $\begin{array}{l}\text { - Government on all } \\
\text { levels: conceal } \\
\text { adaptation costs } \\
\text { - Bureaucracy on all } \\
\text { levels: budget } \\
\text { maximisation } \\
\text { - Interest groups: min. } \\
\text { cost burden of public } \\
\text { adaptation }\end{array}$ & $\begin{array}{l}\text { - Bureaucracy on all } \\
\text { levels: slack } \\
\text { maximisation }\end{array}$ \\
\hline
\end{tabular}

the identification of links to other policy objectives which have a higher political priority (Measham et al., 2011; UNDP/UNEP, 2011; Yohe, 2001). The case is less clear-cut for public bureaucracies. If bureaucrats in the different policy fields are assumed to be budget maximisers which compete for adaptation funds, there may be an incentive to integrate adaptation issues into sectoral policies and procedures. If bureaucrats are rather understood as slack maximisers, which try to reduce efforts for a given budget, there is an incentive to reject the integration of adaptation measures (or only implement it symbolically) and rather shift the responsibility to other policy fields, most notably environmental departments. Which approach eventually dominates, depends on the likelihood to obtain additional budgets for public adaptation. Beck et al. (2011: 5) point out, for example, that no extra budget is provided for implementing the action plan of Germany's adaptation strategy. Rather, adaptation measures shall be funded from existing sectoral budgets through mainstreaming. Based on Public Choice reasoning, however, this provision may in fact be interpreted as an effective impediment to mainstreaming. Table 2 summarises the incentive structure of all stakeholders regarding organisation.

\section{Lessons learnt from German flood disasters}

In the following, we demonstrate how the conceptual framework outlined above sheds some light on a specific empirical example of public adaptation: flood risk management in Germany. To illustrate how the experience of public adaptation 
to flood risks may be traced back to the Public Choice framework, we proceed in three steps. First, we provide an overview on the public adaptation options that could/should be implemented to mitigate flood risks. Second, we summarise the empirically observed adaptation measures in response to flood disasters in Germany. Third, we argue that the empirical evidence hints at barriers to efficient public adaptation which are well in line with the above framework. The discussion of this case study is based on a meta-review of existing academic studies and policy documents for German flood management as well as an application of the Public Choice framework developed in Section 2.

\section{Public adaptation to flood events - options and challenges}

Adaptation to the climate change-induced increase in flood risk may occur in a variety of ways, none of which could eradicate all flood risk by itself. In other words, there is no 'silver bullet' to flood risk management. As indicated in our conceptual framework, an efficient mix of adaptation measures would have to meet three requirements.

First, regarding the extent of public adaptation, $100 \%$ public protection against flood risk is neither efficient (crowding out of private precaution) nor feasible. Thus, private efforts necessarily need to complement public adaptation. Such private precautionary measures may include defensive measures (e.g., building houses on stilts or keeping mobile protective walls ready) and measures such as using water-resistant construction materials and relocating valuable items to higher floors (cf. Kreibich et al., 2005). Moreover, private precaution may consist of disaster insurance. In this regard, a mandatory natural disaster insurance is debated (Schwarze and Wagner, 2007) as one option to prevent a vicious circle of public aid inducing moral hazard and rising premiums for private insurance (cf. section Three dimensions of public adaptation).

Second, the structure of adaptation should reflect a 'balanced mix' of green, technical and societal ${ }^{9}$ as well as reactive and anticipatory measures. Figure 2 illustrates exemplary public adaptation measures for various combinations of form and timing. Overall, an efficient approach towards anticipatory flood risk management cannot rely on a single kind of measure since the marginal opportunity costs of specific measures possibly increase with their extent. This still leaves the question how to trade-off preventive efforts with reactive flood risk management. One could argue that the incidence of disastrous floods follows from the failure of preventive adaptation in the first place. Then again, the expectation of ex-post compensation, such as disaster relief in the immediate aftermath of a flood catastrophe and long-term recovery aid greatly affect the incentives for ex-ante precaution (cf. Dari-Mattiacci and Faure, 2015; Shugarth

9 Flood risk management literature mostly refers to this distinction as structural/non-structural. Yet, we believe the terms technical/societal express more directly what is meant. 
Figure 2. Public adaptation to flood risk.

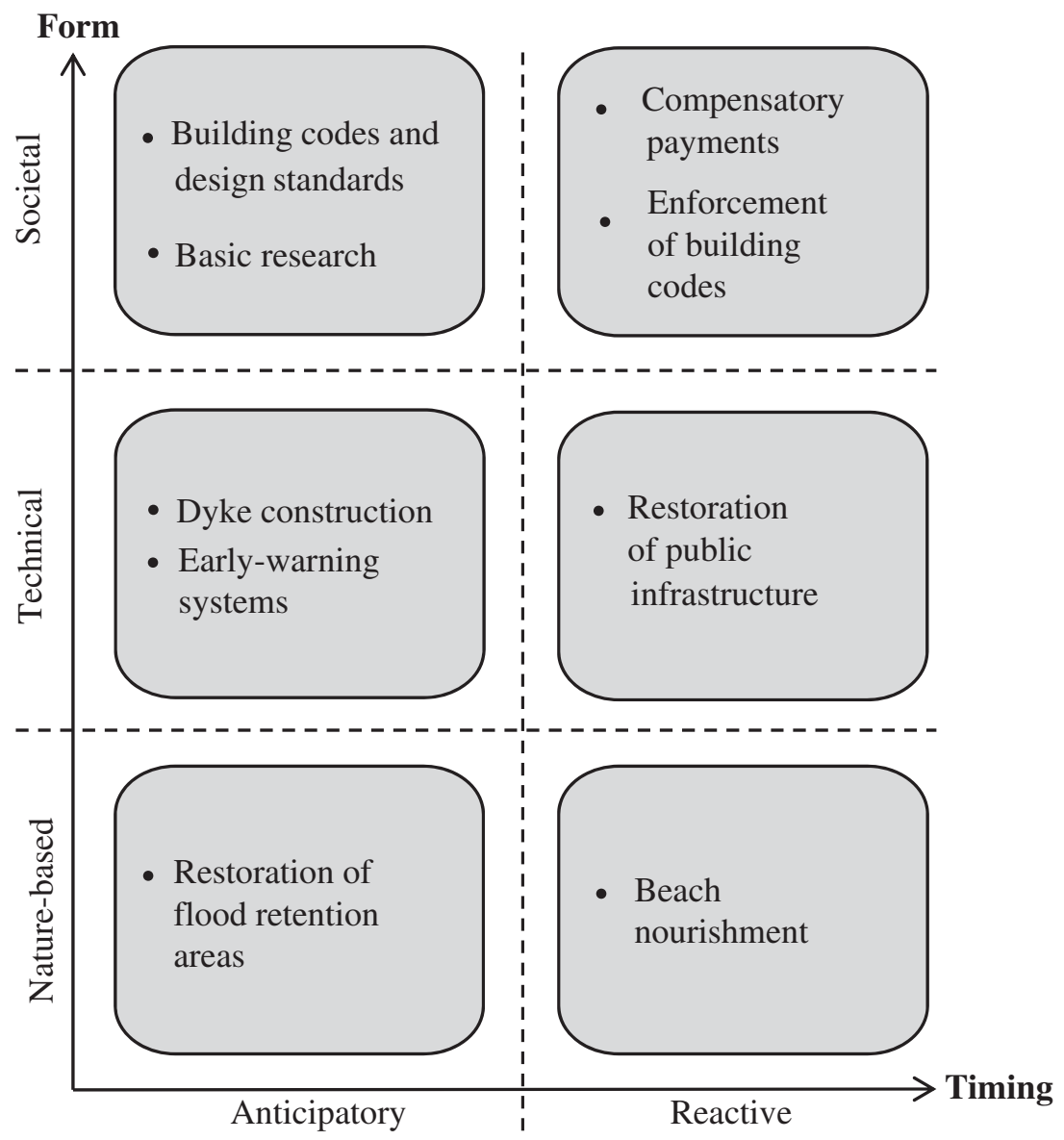

II, 2006). And as we see below, disaster relief and recovery aid form an important part of the actual public response to flood risk in Germany.

Third, the organisation of flood risk management for multi-level and regionally diverse entities faces a considerable challenge: The protection from flood risks constitutes a public good but the spatial distribution of affected stakeholders may not coincide with the political constituencies. In order to internalise all spill-over effects (no pun intended), responsibilities within the public provision of flood protection need to be allocated so as to match the spatial range of public adaptation measures with political representation. Also, organisation of flood risk management across territorial authorities should take the benefits of both decentralisation and centralisation into account: Locals possess important knowledge over case-specific details while policy coordination across governance levels may yield economies of scale. In particular, coordinated river basin management over all affected countries, states and municipalities 
Table 3 Extreme flood events, damages, and public disaster relief in Germany since 1997

\begin{tabular}{|c|c|c|}
\hline $\begin{array}{l}\text { Flood year and most affected } \\
\text { major rivers }\end{array}$ & $\begin{array}{l}\text { Damage (estimate } \\
\text { in bn } € \text { for the } \\
\text { whole of Germany) }\end{array}$ & $\begin{array}{l}\text { Public disaster relief and recovery aid } \\
\text { (estimate in bn } € \text { for the whole of Germany) }\end{array}$ \\
\hline 1997 Oder flood & $0.3-0.6$ & 0.5 \\
\hline 1999 Donau flood & 0.5 & no information/no significant public aid \\
\hline 2002 Elbe and Donau flood & 10 & 7.1 \\
\hline 2006 Elbe flood & 0.1 & no information/no significant public aid \\
\hline 2010 Oder flood & 0.9 & no information/no significant public aid \\
\hline 2013 Elbe and Donau flood & 6.7 & 8 \\
\hline
\end{tabular}

Source: compiled by the authors, based on Bundestag (1997), DKKV (2003), Deutsche Rück (2004, 2006, 2010), BMI (2013), SäSK (2011).

would be required to efficiently manage flood risk. For instance, the river Elbe passes through eleven regions in two countries, the Czech Republic and Germany, all of which would need to coordinate flood protection. What is more, integration within existing emergency relief structures in other policy fields would be preferable so as to enable cost-efficient implementation of reactive adaptation measures.

Overall, our analysis suggests that the optimal mix of adaptation measures to mitigate flood risks cannot be determined without reference to context-specific factors - more generally, a range of measures needs to be considered (DKKV, 2003, 2013; Meyer et al., 2013). For instance, Meyer et al. (2013) propose that anticipatory flood risk management should comprise the four pillars of (1) technical flood protection, (2) natural protection, (3) private precaution and (4) mandatory insurance. To be sure, numerous uncertainties (see, e.g., Watkiss et al., 2015) imply that the abstract concept of an efficient benchmark necessarily remains vague when applied to the broad empirical setting of German flood protection. Thus, the subsequent comparison of empirical evidence and hypothetical benchmark does not claim to be objective or definitive. Rather, any such evaluation carries an inherently subjective component.

\section{Empirical evidence: extreme floods and adaptation measures in Germany 1997-2013}

Since 1997, Germany has witnessed a number of extreme flood events (see Table 3). In particular, in the Elbe catchment, covering large parts of Northern Czech Republic and Eastern Germany, two extreme flood events occurred within only 11 years, with discharge levels in parts of the main river and some of its tributaries which, statistically, would have to be expected only every 100 years or even less frequently (DKKV, 2013). Damages caused by the Elbe and Danube flood in August 2002 were most severe, with 21 deaths and about 10 bn $€$ financial damage in Germany. Public relief efforts were sizeable. In contrast, 
when in 2006 the river Elbe also flooded parts of the most affected areas from the 2002 flood in South Eastern Saxony (the overall damage was rather low compared to 2002) no substantial government funds were handed out. In 2013, another extreme flood caused large financial damages at around 6.7 bn $€$ and 8 casualties - because most of the new levees, which were built after 2002, held and the respective cities were not flooded. Furthermore, a recovery aid fund for up to 8 bn $€$ was installed.

As regards the three dimensions of public adaptation, the following picture of flood risk management in Germany emerges:

First, as Table 3 makes clear, the extent of reactive public adaptation in the form of relief and recovery efforts is very large. This becomes particularly obvious when comparing the extent of actual public funds to the legal provisions set up to distribute the responsibilities of flood risk management between individuals and the government. The 'Federal Water Act' stipulates that all individuals have a general duty of care to implement 'reasonable' precautionary measures to mitigate flood risk for themselves or their property (Wasserhaushaltsgesetz (WHG) - Federal Water Act, 2009, Section 5(2)). Furthermore, laws on the regional level (Bundesländer) exempt the regional governments from any duty to provide $100 \%$ protection against floods - for instance, the Bavarian 'immediate assistance guidelines' restrict emergency relief measures to hardship cases. However, Table 3 rather tells a story of ad-hoc public disaster relief and recovery aid. Emergency relief - if provided at all - is full. This uncertainty whether public aid is granted at all should induce individuals to engage in private precautionary efforts and limit crowding out. ${ }^{10}$ Indeed, overall insurance density against elementary risks in Germany has been steadily rising, suggesting an increase of private risk consciousness: In 2012, insurance density reached $32 \%$, against $19 \%$ ten years earlier (BMI, 2013). Moreover, Osberghaus (2015) finds little empirical evidence for crowding out of private mitigation measures by insurance. These trends notwithstanding, a remainder of buildings in the most flood-prone areas has no chance of receiving regular insurance cover on the free market (e.g., in Bavaria, $1.5 \%$ of buildings are considered uninsurable, UBA (2011: 57)). Basically, there are two main options to deal with such settlements: either the government credibly commits to not providing emergency relief in their case (as advocated by Shughart II (2006), for instance) or one sets up a mandatory insurance scheme (see Schwarze and Wagner (2007)). Even though the topic has been repeatedly brought forward in public debates (Osberghaus

10 Raschky et al. (2013) argue that such a limited relief is more effective when the grant as such is uncertain compared to an uncertain degree of coverage (as is the case in Austria). Moreover, the emergency relief should be restricted to the most essential needs, such that the incentives for private actors to invest in precautionary measures are kept as strong as possible, and be distributed among those affected according to the needs, so as to maximise the benefit of a given amount of relief (Osberghaus et al., 2010). 
and Mennel, 2014), for instance by several politicians in the wake of the 2013 flood, no such scheme has been implemented so far (Jahberg, 2014).

Second, as regards the structure of flood risk management, technical measures remain very popular. In the wake of the 2002 flood, for instance, large investments in technical measures were carried out: In Saxony alone, 650 million $€$ were spent by 2014, mostly on concrete walls and levees to protect cities from the Elbe and its tributaries (SMUL, 2014b). One reason behind these pronounced technical efforts is that only a fraction of the original retention areas now provide flood protection. For instance, $86 \%$ of the former 6.172 ha. natural plains along the Elbe have disappeared (UBA, 2011: 22). Their recovery is prone to conflicts because of the trade-offs with surrender of agricultural land or even settlements. In consequence, although it is widely acknowledged that natural floodplains provide an important and partly non-substitutable form of flood protection, only three out of 49 originally planned projects had been realised in the State of Saxony by 2013 (SMUL, 2014a).

Third, the organisation of flood risk management in Germany puts the main responsibility with the states. Thus, the Bundesländer set up plans for managing anticipatory and reactive adaptation measures. For instance, the state of Saxony has implemented a risk management scheme that includes a ranking of technical measures to be built in the future (Schanze et al., 2008). Nevertheless, the federal government enters the scene whenever a highly media-covered flood event occurs (see below). As regards the Elbe, one of the most concerned rivers in the 2002 and 2013 floods, a main challenge consists in coordinating risk management both within Germany on regional and communal governance levels and between Germany and the Czech Republic.

In the following, we argue that the observed pattern of flood risk management in Germany displays politico-economic biases in line with the conceptual framework elaborated in Section 2. To that end, we investigate how extent, structure and organisation of flood risk management in Germany may deviate from a hypothetical efficient mix of adaptation.

\section{Applying the public choice framework: evidence for biases}

The previous discussion has revealed that the extent of public adaptation in terms of emergency relief and recovery aid provided - has been varying with flood events in Germany. The uncertain relief has probably not been purposefully chosen for limiting the crowding out effect, but it rather has derived from the respective incumbent governments' incentive to adjust the amount of support to the level of media attention and on whether elections are due or not. One might speak of two different modes of policy-making here, the normal non-crisis mode and the crisis mode (e.g., Alesina and Drazen, 1991; Drazen and Easterly, 2001; Fidrmuc and Tichit, 2013): From this perspective, flood catastrophes represent a prime example of the crisis mode in that they are characterised by strong public pressure for immediate and visible political responses (even if 
only symbolic, Edelman (1964)) and by extraordinary leeway for politicians to take advantage of the attention cycle; normal budget constraints (opportunity costs) are temporarily suspended due to public acceptance of extra expenditures which enables 'consumption binges' (Rogoff, 1990). As a consequence, damages are likely to be overcompensated (type I barrier) - even more so in election years, when the political budget cycle draws to an end (Citlak and Wagner, 2001, type I barrier). This can be seen from the flood in Germany in 2002 which helped chancellor Schröder to be re-elected the same year. Specifically, Bechtel and Hainmueller (2011: 851) argue that the flood relief programs (a 7.1 bn $€$ recovery fund was set up) increased the incumbent party's vote share in affected areas by $7 \%$ in the 2002 federal elections; what is more, the targeted recovery aid not only delivered short-term rewards but also yielded longer lasting effects: about a quarter of the short term reward carried over to the next general election in 2005 where the incumbent party's vote share in affected areas was still $2 \%$ higher than it would have been without the flood. Only at the end of the subsequent election cycle, in 2009, the 2002 flood has shown no more discernible effect on voter behaviour (ibid.). In comparison with the 2002 flood, the overall damages in 2006 were far lower and the event also received less attention in national media. Furthermore, the flood occurred at the beginning of the election cycle, so the federal government's incentive to intervene was low. In 2013, another extreme flooding occurred within months before a general election. While there are not yet any detailed analyses on the 2013 relief's electoral impact comparable to the analyses for 2002, the extent of the damages and the event's timing at the end of the electoral cycle made full and imminent relief efforts a political necessity for the incumbent government. Note that the 2013 flood recovery fund (Sondervermögen 'Aufbaubilfe') explicitly comprises more money than the official sum of damages (BMI, 2013, see Table 4). In conclusion, the actual extent of public disaster relief and recovery in Germany seems to be heavily determined by the level of media attention and political expediency (e.g., Eisensee and Strömberg, 2007). This is not to belittle the regional efforts to consistently hedge flood risks through anticipatory measures - yet, the politico-economic characteristics of the overall public response to flood risks remain.

Regarding the structure of adaptation, the above framework also helps to explain the perceived prevalence of technical measures. From a voter perspective, the anticipatory mitigation of flood risks through large-scale technical measures, financed via public budgets, seems preferable compared to ex-post compensation that does not cover the 'psychological' costs of experiencing a flood disaster. Furthermore, large-scale technical preventive measures possibly inhibited the sufficient implementation of complementary societal measures: Empirical studies demonstrated that the reinforced or newly built levees convey a sense of certainty for most individuals (Kuhlicke and Steinführer, 2007: 101). Not only is this sense of certainty deceptive, but also does it prompt individuals to move into supposedly 'safe' zones. In the long run, this may lead to spiralling costs, 
higher even than without any technical measures. Moreover, technical protection reduces the expected damage from an individual point of view and reduces the incentive to carry out private precautionary measures (Meyer et al., 2012). In terms of timing, flood risk management has been criticised for not sufficiently emphasizing preventive measures like restoration of natural floodplains in the respective legal provisions (Reese, 2011).

As regards the organisation of adaptation, Germany's federally organised system may pose some challenges for implementing efficient flood risk management. Indeed, for the 2002 flood, communication between authorities on different government levels and from different regions seems to have been problematic; however, due to this experience responsibilities have been centralised on the level of the states, the overall perception being that coordination has improved since then (DKKV, 2013). Concerning mandatory insurance, distributional conflicts between federal and state administrations have been identified as one important reason inhibiting its introduction in Germany (Schwarze and Wagner, 2007); also, the insurance industry lobbies against such proposals (Jahberg, 2014). To be sure, the transnational character of river basins intensifies the challenge of organisation across territorial authorities at the same policy level. For instance, although the EU's relevant directive 2007/60/EC requires transnational coordination, the handling of retention areas next to Prague during the 2013 Elbe flood has been criticised by downstream municipalities, both in Germany and the Czech Republic (Schmidt, 2013).

In sum, some of the characteristics of existing flood-related policies in Germany well align with the premises of Public Choice theory: The extent of flood disaster relief is driven by media coverage and influenced by the electoral cycle, the structure of flood risk management shows a bias towards technical and anticipatory measures and the organisation of flood risk management faces the pitfalls of coordinated action across regional and national boundaries. Overall, the main bias of the observed pattern of flood disaster relief is its ad-hoc nature. This is not to say that all flood risk management is arbitrary. For example, there exist consistent long-term strategies for the spatial allocation of technical measures on state level. However, due to the $a d-h o c$ nature of disaster relief, not all non-protected areas necessarily receive sufficient disaster relief. Media attention and flood events' timing within electoral cycles are crucial variables in explaining why disaster relief is granted or not. ${ }^{11}$ These biases, in turn, feed back into and possibly distort private precautionary and public anticipatory efforts.

11 Experiences after the 2005 Hurricane Katrina can be traced back to politico-economic incentives in a similar way. For instance, 'glory seeking' prevented efficient disaster management: policy makers confiscated private organisations' supplies in order to achieve more recognition (and finally votes) on their own behalf (Sobel and Leeson, 2006). Furthermore, numerous coordination problems between different levels of government yielded confusion and led to suboptimal relief efforts (Congleton, 2006). 
In other words, overall adaptation output is co-determined by the perceived severity of recurring crises.

\section{Conclusions}

This paper provides a Public Choice perspective on public adaptation to climate change. Using this approach, we contribute to answering the question why political actors may lack incentives to adopt an efficient level of public adaptation - even if they have sufficient information and resources available. We distinguish three dimensions of public adaptation: extent (investment level/effort), structure (timing - preventive vs. reactive measures; form - technical vs. societal measures), and organisation (coordination across territorial authorities and policy fields). Within each of these dimensions, Public Choice expects actual adaptation measures to deviate from the efficient benchmark. This not only concerns public adaptation as such, but also related private adaptation measures 'insofar as government rules determine private rates of return at the margin' (Congleton, 2006: 23). Overall, stakeholders' self-interest biases adaptation towards centralisation of decisions, as well as to technical and to reactive measures.

The experience of German flood disasters from 1997-2013 reveals a trend toward ad-hoc recovery efforts, mainly driven by the level of media attention. While the legal provisions clearly stipulate that individuals bear the main responsibility for flood risk precaution and should only receive immediate emergency relief, these guidelines have been repeatedly ignored if political expediency required so. Given the public pressure in the aftermath of catastrophic events, politicians striving for re-election cannot credibly commit ex ante to restrict public aid to efficient levels. This, however, would be necessary to sufficiently induce private actors to engage in self-prevention. Thus, the German flood responses revealed an ad-hoc approach where the extent and timing of disastrous events within the electoral cycle also affected the extent of recovery aid; this ad-hoc nature of recovery aid exacerbates the challenge of consistent overall flood risk management. In effect, this leaves a small part of potentially affected population completely unprotected as their location is deemed uninsurable and no technical measures are in place. On the contrary, sizeable flood-prone areas lack proper incentives for private precautionary efforts because levees and dams convey a deceptive sense of safety.

In conclusion, normative economic analyses of public adaptation need to confront the inconvenient truth that actual public adaptation does not always and not in all areas proceed as advised. The question how to deal with this fact in devising policy recommendations possibly points towards adaptation of research frameworks. Instead of decrying 'monumental governmental failure' and praising the virtues of private action, both in individual precaution and the provision of public goods (Shughart II, 2006: 49), economic analyses might be 
better advised to conceive of the interest-based nature of policy formulation as an inevitable restriction - politico-economic restrictions that cannot be neglected and should form the basis of any meaningful policy analysis.

\section{Acknowledgements}

We are grateful for very helpful discussions with Christian Kuhlicke and Volker Meyer on earlier versions of this manuscript. We would like to thank Frank Hirschi for excellent research assistance. Moreover, we appreciate valuable comments of two anonymous referees.

\section{References}

Alesina, A. and A. Drazen (1991), 'Why are Stabilizations Delayed?', American Economic Review, 81: 1170-1188.

Bechtel, M. and J. Hainmueller (2011), 'How Lasting is Voter Gratitude? An Analysis of the Short- and Long-Term Electoral Returns to Beneficial Policy', American Journal of Political Science, 55(4): 852-868.

Beck, S., C. Kuhlicke, and C. Görg (2009), Climate Policy Integration, Coherence, and Governance in Germany. PEER Climate Change Initiative - Project 2, Leipzig: Helmholtz Centre for Environmental Research - UFZ.

Beck, S., J. Bovet, S. Baasch, P. Reiß, and C. Görg (2011), Synergien und Konflikte von Strategien und Maßnahmen zur Anpassung an den Klimawandel, Dessau: Umweltbundesamt.

Biesbroek, G. R., J. Klostermann, C. Termeer, and P. Kabat (2013), 'On the Nature of Barriers to Climate Change Adaptation', Regional Environmental Change, 13(5): 1119-1129.

Blankart, C. B. (2011), Öffentliche Finanzen in Der Demokratie: Eine Einführung in Die Finanzwissenschaft, München: Vahlen.

BMI (2013), Bericht zur Flutkatastrophe 2013. Katastrophenhilfe, Entschädigung, Wiederaufbau, Berlin: Bundesministerium des Innern (BMI).

Browne, M. and R. Hoyt (2000), 'The Demand for Flood Insurance: Empirical Evidence', Journal of Risk and Uncertainty, 20(3): 291-306.

Bryant, C. R., B. Smit, M. Brklacich, T. R. Johnston, J. Smithers, Q. Chjotti, and B. Singh (2000), 'Adaptation in Canadian Agriculture to Climatic Variability and Change', Climatic Change, 45(1): 181-201.

Bundestag (1997), Unterrichtung durch die Bundesregierung - Abschlussbericht zur Hochwasserkatastrophe an der Oder, Drucksache 13/9571, Berlin: Deutscher Bundestag.

Citlak, B. and G. Wagner (2001), 'Hochwasser: Unkalkulierbare Ereignisse und Unvermeidbare Folgen? Denkanstösse für den ökonomischen Umgang mit Elementarschäden', in H. -C. Mager, H. Schäfer and K. Schrüfer (eds.), Private Versicherung und Soziale Sicherung - Festschrift zum 60. Geburtstag von Roland Eisen, Marburg: Metropolis, pp. 97-111.

Congleton, R. D. (2006), 'The Story of Katrina: New Orleans and the Political Economy of Catastrophy', Public Choice, 127: 5-30. 
Corfee-Morlot, J., I. Cochran, S. Hallegatte, and P.-J. Teasdale (2011), 'Multilevel Risk Governance and Urban Adaptation Policy', Climatic Change, 104: 169197.

Dari-Mattiacci, G. and M. G. Faure (2015), 'The Economics of Disaster Relief', Law \& Policy, 37(3): 180-208.

Deutsche Rück (2004), Sturmdokumentation Deutschland 1997-2004, Düsseldorf: Deutsche Rück.

Deutsche Rück (2006), Sturmdokumentation Deutschland 2006, Düsseldorf: Deutsche Rück. Deutsche Rück (2010), Sturmdokumentation Deutschland 2010, Düsseldorf: Deutsche Rück. DKKV (2003), Hochwasservorsorge in Deutschland - Lernen aus der Katastrophe 2002 im Elbegebiet, Bonn: Deutsches Komitee für Katastrophenvorsorge e. V. (DKKV).

DKKV (2013), Das Hochwasser im Juni 2013, Bonn: Deutsches Komitee für Katastrophenvorsorge e. V. (DKKV).

Downs, A. (1957), An Economic Theory of Democracy, New York: Harper.

Drazen, A. and W. Easterly (2001), 'Do crises induce reform? Simple Empirical Tests of Conventional Wisdom', Economics and Politics, 13(2): 129-157.

Edelman, M. (1964), The Symbolic Uses of Politics, Urbana: University of Illinois Press.

Eisenack, K. and R. Stecker (2012), 'A Framework for Analyzing Climate Change Adaptations as Actions', Mitigation and Adaptation Strategies for Global Change, 17(3): 243-260.

Eisensee, T. and D. Strömberg (2007), 'News Droughts, News Floods, and U.S. Disaster Relief', Quarterly Journal of Economics, 122(2): 693-728.

Falaleeva, M., C. O’Mahony, S. Gray, M. Desmond, J. Gault, and V. Cummins (2011), 'Towards Climate Adaptation and Coastal Governance in Ireland: Integrated Architecture for Effective Management?', Marine Policy, 35: 784-793.

Fidrmuc, J. and A. Tichit (2013), 'How I learned to Stop Worrying and Love the Crisis', Economic Systems, 37: 542-554.

Füssel, H.-M. (2007), 'Adaptation Planning for Climate Change: Concepts, Assessment Approaches and Key Lessons', Sustainability Science, 2(2): 265-275.

Füssel, H.-M. and R. J. T. Klein (2004), Conceptual Frameworks of Adaptation to Climate Change and Their Applicability to Human Health, Potsdam: Potsdam Institute for Climate Impact Research (PIK).

Gill, S. E., J. F. Handley, A. R. Ennos, and S. Pauleit (2007), 'Adapting Cities for Climate Change: The Role of the Green Infrastructure', Built Environment, 33(1): 115-133.

Gupta, J., C. J. A. M. Termeer, J. Klostermann, S. Meijerink, M. van den Brink, P. KJong, S. Nooteboom, and E. Bergsma (2010), 'The Adaptive Capacity Wheel: A Method to Assess the Inherent Characteristics of Institutions to Enable the Adaptive Capacity of Society', Environmental Science and Policy, 13: 459-471.

Heuson, C., E. Gawel, O. Gebhardt, B. Hansjürgens, P. Lehmann, V. Meyer, and R. Schwarze (2012), Fundamental Questions on the Economics of Climate Adaptation - Outlines of a New Research Programme, Leipzig: Helmholtz Centre for Environmental Research UFZ.

Inman, R. P. and D. L. Rubinfeld (1997), 'The Political Economy of Fiscal Federalism', in D. C. Mueller (ed.), Perspectives on Public Choice: A Handbook, Cambridge, UK: Cambridge University Press, pp. 73-105.

Jahberg, H. (2014), 'Streit um Zwangspolicen gegen Naturkatastrophen', [online], Available at: http://www.tagesspiegel.de/wirtschaft/pflichtversicherung-gegenelementarschaeden-streit-um-zwangspolicen-gegen-naturkatastrophen/9987370.html\#. (accessed 14/07/2016). 
Klein, R. J. T., G. F. Midgley, B. L. Preston, M. Alam, F. Berkhout, K. Dow, and M. R. Shaw (2014), 'Adaptation Opportunities, Constraints, and Limits', in C. B. Field, V. R. Barros, D. J. Dokken, K. J. Mach, M. D. Mastrandrea, T. E. Bilir, M. Chatterjee, K. L. Ebi, Y. O. Estrada, R. C. Genova, B. Girma, E. S. Kissel, A. N. Levy, S. MacCracken, P. R. Mastrandrea, and L. L. White (eds.), Climate Change 2014: Impacts, Adaptation, and Vulnerability. Part A: Global and Sectoral Aspects. Contribution of Working Group II to the Fifth Assessment Report of the Intergovernmental Panel on Climate Change, Cambridge, UK and New York, USA: Cambridge University Press, pp. 899-943.

Kreibich, H., A. H. Thieken, T. Petrow, M. Müller, and B. Merz (2005), 'Flood Loss Reduction of Private Households Due to Building Precautionary Measures - Lessons Learned from the Elbe Flood in August 2002', Natural Hazards and Earth System Sciences, 5: 117126.

Krueger, A. O. (1974), 'The Political Economy of the Rent-Seeking Society', American Economic Review, 64(3): 291-303.

Kuhlicke, C. and A. Steinführer (2007), 'Wider die Fixiertheit im Denken - Risikodialoge über Naturgefahren', GAIA, 15(4): 265-274.

Kunreuther, H. and M. Pauly (2004), 'Neglecting Disaster: Why Don't People Insure Against Large Losses?', Journal of Risk and Uncertainty, 28(1): 5-21.

Lebel, L., J. B. Manuta, and P. Garden (2011), 'Institutional Traps and Vulnerability to Changes in Climate and Flood Regimes in Thailand', Regional Environmental Change, 11(1): 45-58.

Lehmann, P., M. Brenck, O. Gebhardt, S. Schaller, and E. Süßbauer (2015), 'Barriers and Opportunities for Urban Adaptation Planning: Analytical Framework and Evidence from Cities in Latin America and Germany', Mitigation and Adaptation Strategies for Global Change, 20(1): 75-97.

McCarthy, J. J., O. F. Canziani, N. A. Leary, D. J. Dokken, and K. S. White (2001), Climate Change 2001: Impacts, Adaptation, and Vulnerability. Contribution of Working Group II to the Third Assessment Report of the Intergovernmental Panel on Climate Change, Cambridge, UK, and New York, USA: Cambridge University Press.

Measham, T., B. L. Preston, T. F. Smith, C. Brooke, R. Gorddard, G. Withycombe, and C. Morrison (2011), 'Adapting to Climate Change Through Local Municipal Planning: Barriers and Challenges', Mitigation and Adaptation Strategies for Global Change, 16(8): 889-909.

Meyer, V., C. Kuhlicke, R. Schwarze, M. Scholz, D. Haase, and J. Luther (2013), $100 \%$ Flood Protection is Not Possible - We Need Four Pillars of Sustainable Flood Mitigation and Adaptation Measures, Available at: https://www.ufz.de/ export/data/global/50009_statement_flood_protectionl.pdf.

Meyer, V., S. Priest, and C. Kuhlicke (2012), 'Economic Evaluation of Structural and NonStructural Flood Risk Management Measures: Examples from the Mulde River', Natural Hazards, 62(2): 301-324.

Michaelowa, A. (2001), Mitigation Versus Adaptation: The Political Economy of Competition Between Climate Policy Strategies and the Consequences for Developing Countries, Hamburg: Hamburgisches Welt-Wirtschafts-Archiv (HWWA).

Michaelowa, A. and K. Michaelowa (2011), 'Coding Error or Statistical Embellishment? The Political Economy of Reporting Climate Aid', World Development, 39(11): 2010-2020. 
Mickwitz, P., F. Aix, S. Beck, D. Carss, N. Ferrand, C. Görg, A. Jensen, P. Kivimaa, C. Kuhlicke, W. Kuindersma, M. Mánez, M. Melanen, S. Monni, A. B. Pedersen, H. Reinert, and S. van Bommel (2009), Climate Policy Integration, Coherence and Governance, Helsinki: Partnership for European Environmental Research (PEER).

Moser, S. C. and J. A. Ekstrom (2010), 'A Framework to Diagnose Barriers to Climate Change Adaptation', Proceedings of the National Academy of Sciences, 107(51): 22026-22031.

Mueller, D. C. (2003), Public Choice III, 3rd ed., Cambridge: Cambridge University Press.

Musgrave, R. (1959), The Theory of Public Finance, New York: McGraw Hill.

Næss, L. O., G. Bang, S. Eriksen, and J. Vevatne (2005), 'Institutional Adaptation to Climate Change: Flood Responses at the Municipal Level in Norway', Global Environmental Change, 15: 125-138.

Niskanen, W. A. (1971), Bureaucracy and Representative Government, Atherton: Aldine Transaction.

Oates, W. E. (1972), Fiscal Federalism, New York: Harcourt Brace Jovanovich.

Oberlack, C. (2016), 'Diagnosing Institutional Barriers and Opportunities for Adaptation to Climate Change', Mitigation and Adaptation Strategies for Global Change: DOI 10.1007/s11027-015-9699-z.

Olson, M. (1969), 'The Principle of "Fiscal Equivalence”: The Division of Responsibilities among Different Levels of Government', American Economic Review, 59: 479-487.

Olson, M. (1971), The Logic of Collective Action: Public Goods and the Theory of Groups, Cambridge, MA: Harvard University Press.

Osberghaus, D. (2015), 'The Determinants of Private Flood Mitigation Measures In Germany - Evidence from a Nationwide Survey', Ecological Economics, 110: 36-50.

Osberghaus, D. and T. Mennel (2014), 'Hochwasservorsorge zwischen Staatshilfen und privater Versicherung, Wirtschaftsdienst, 94(8): 583-587.

Osberghaus, D., A. Dannenberg, T. Mennel, and B. Sturm (2010), 'The Role of the Government in Adaptation to Climate Change', Environment and Planning C: Government and Policy, 28: 834-850.

Peltzman, S. (1976), 'Toward a More General Theory of Regulation', Journal of Law and Economics, 19(2): 211-240.

Penning-Rowsell, E., C. Johnson, and S. Tunstall (2006), “Signals' from Pre-Crisis Discourse: Lessons from UK Flooding for Global Environmental Policy Change?', Global Environmental Change, 16: 323-339.

Porrini, D. and R. Schwarze (2014), 'Insurance Models and European Climate Change Policies: An Assessment', European Journal of Law and Economics, 38: 7-28.

Raschky, P. and H. Weck-Hannemann (2007), 'Charity Hazard - A Real Hazard in Natural Disaster Insurance?’, Environmental Hazards, 7(4): 321-329.

Raschky, P., R. Schwarze, M. Schwindt, and F. Zahn (2013), 'Uncertainty of Governmental Relief and the Crowding Out of Flood Insurance', Environmental and Resource Economics, 54(2): 179-200.

Reese, M. (2011), 'Das neue Recht des Hochwasserschutzes vor den Herausforderungen des Klimawandels', Natur und Recht, 33: 19-28.

Rogoff, K. (1990), 'Equilibrium Political Budget Cycles', American Economic Review, 80(1): 21-36.

Runhaar, H., H. Mees, A. Wardekker, J. van der Sluijs, and P. P. J. Driessen (2012), 'Adaptation to climate change-related risks in Dutch urban areas: stimuli and barriers', Regional Environmental Change, 12: 777-790. 
SäSK (2011), Der Wiederaufbau im Freistaat Sachsen nach dem Hochwasser im Juni 2013, Dresden: Sächsische Staatskanzlei (SäSK).

Schanze, J., E. Penning-Rowsell, H.-P. Nachtnebel, V. Meyer, A. Werritty, T. Harries, H. Holzmann, B. Jessel, P. Koeniger, C. Kuhlicke, C. Neuhold, A. Olfert, D. Parker, and A. Schildt (2008), Systematisation, Evaluation and Context Conditions of Structural and Non-Structural Measures for Flood Risk Reduction. FLOOD-ERA Joint Report, London, UK: ERA-NET CRUE.

Schmidt, H.-J. (2013), 'Ist Tschechiens Egoismus schuld an der Elbeflut?', [online], Available at: http://www.welt.de/vermischtes/article116841325/Ist-Tschechiens-Egoismusschuld-an-der-Elbeflut.html. (accessed 14/07/2016).

Schwarze, R. and G. Wagner (2007), 'The Political Economy of Natural Desaster Insurance: Lessons from the Failure of a Proposed Compulsary Insurance Scheme in Germany', European Environment, 17 403-415.

Shughart, W. F. II (2006), 'Katrinanomics: The Politics and Economics of Desaster Relief', Public Choice, 127: 31-53.

Smit, B., I. Burton, R. J. T. Klein, and R. Street (1999), 'The Science of Adaptation: A Framework for Assessment', Mitigation and Adaptation Strategies for Global Change, 4(3): 199-213.

SMUL (2014a), Antwort auf die Kleine Anfrage "Finanzielle Ausgaben und Stand der realisierten Deichrückverlegungen 2002 bis 2014 - Vorbeugender Hochwasserschutz in Sachsen” (Drs. 5/14565), Dresden: Sächsisches Ministerium für Umwelt und Landwirtschaft (SMUL).

SMUL (2014b), Medieninformation. Sachsen ist bei Hochwasserschutz auf dem richtigen Weg, Dresden: Sächsisches Staatsministerium für Umwelt und Landwirtschaft (SMUL).

Sobel, R. and P. Leeson (2006), 'Government's Response to Hurricane Katrina: A Public Choice Analysis', Public Choice, 127(1): 55-73.

Sovacool, B. K., B.-O. Linnér, and M. E. Goodsite (2015), 'The Political Economy of Climate Adaptation', Nature Climate Change, 5: 616-618.

Stigler, G. J. (1971), 'The Theory of Economic Regulation', Bell Journal of Economics, 2(1): $3-21$.

Tiebout, C. M. (1956), 'A Pure Theory of Local Expenditures', Journal of Political Economy, 64: 416-424.

UBA (2011), Hochwasser. Verstehen, Erkennen, Handeln!, Dessau-Roßlau: Umweltbundesamt (UBA).

UNDP/UNEP (2011), Mainstreaming Climate Change Adaptation into Development Planning: A Guide for Practitioners, Nairobi: United Nations Development Programme (UNDP)/United Nations Environment Programme (UNEP).

Vaubel, R. (1994), 'The Political Economy of Centralization and the European Union', Public Choice, 81: 151-190.

Wasserhaushaltsgesetz (WHG) - Federal Water Act (2009), [online], Available at: http://www.gesetze-im-internet.de/bundesrecht/whg_2009/gesamt.pdf. (accessed 14/07/2016).

Watkiss, P., A. Hunt, W. Blyth, and J. Dyszynski (2015), 'The Use of New Economic Decision Support Tools for Adaptation Assessment: A Review of Methods and Applications, Towards Guidance on Applicability', Climatic Change, 132(3): 401-416.

Wyckoff, P. G. (1990), 'The Simple Analytics of Slack-Maximizing Bureaucracy', Public Choice, 67(1): 35-47.

Yohe, G. W. (2001), 'Mitigative Capacity - The Mirrow Image of Adaptive Capacity on the Emissions Side', Climatic Change, 49: 247-262. 